\title{
Semliki Forest Virus as a Vector: Pros and Cons for Its Use in Biopharmaceuticals Production
}

\author{
Eutimio Gustavo Fernández Núñez ${ }^{1,2 *}$, Soraia Attie Calil Jorge ${ }^{3}$, Renato Mancini Astray ${ }^{3}$, \\ Alexandre Gonçalves de Rezende ${ }^{3}$, Bruno Labate Vale da Costa ${ }^{4}$, Daniella Cristina Ventini \\ Monteiro ${ }^{1,3}$, Carlos Augusto Pereira ${ }^{1,3}$ and Aldo Tonso ${ }^{1}$ \\ ${ }^{1}$ Laboratório de Células Animais; Departamento de Engenharia Química; Escola Politécnica; Universidade de São \\ Paulo; São Paulo - SP - Brasil. ${ }^{2}$ Departamento de Ciências Biológicas; Faculdade de Ciência e Letras; \\ Universidade Estadual Paulista "Julho de Mesquita Filho"; Assis - SP - Brasil. ${ }^{3}$ Laboratório de Imunologia Viral; \\ Instituto Butantan; São Paulo - SP - Brasil. ${ }^{4}$ Laboratório de Biotecnologia Industrial; Núcleo de \\ Bionanomanufatura; Instituto de Pesquisas Tecnológicas do Estado de São Paulo; São Paulo - SP - Brasil
}

\begin{abstract}
The number of biopharmaceuticals for medical and veterinarian use produced in mammalian cells is increasing year after year. All of them are obtained by stable recombinant cell lines. However, it is recognized that transient gene expression produces high level expression in a short time. In that sense, viral vectors have been extensively used for producing recombinant proteins on lab-scale. Among them, Semliki Forest virus is commonly employed for this purpose. This review discusses the main aspects related to the use of Semliki Forest virus technology as well as its advantages and drawbacks which limit currently its utilization in biopharmaceutical industry on large-scale.
\end{abstract}

Key words: BHK-21, Large-scale bioprocesses, Mammalian cells, Recombinant proteins, SFV, Transient expression

\section{INTRODUCTION}

Mammalian cells have become the major host for recombinant proteins used as biopharmaceuticals with medical and veterinarian applications (Baldi et al. 2007; Conceição et al. 2007). The main factor related to this extensive application is the need of post-translational modifications in order to guarantee the full bioactivity of these macromolecules. Such changes are only accurately performed by the mammalians cells (Walsh 2010). Currently, there are two established strategies in biopharmaceutical industry and academy to produce heterologous proteins: the use of stable cell lines, or transient gene expression (Kerrigan et al. 2011). The first one is achieved through the insertion of the recombinant gene(s) into the host genome. This approach is useful to produce recombinant protein for extended cultivation times. However, the identification and characterization processes of these cell lines are expensive and prolonged (De Jesus and Wurm 2011). On the other hand, when rapid assessment of many proteins, or several variants of a single protein is required, transient gene expression is the strategy of choice. Furthermore, short upstream processes (1-14 days) are related with transient gene expression (De Jesus and Wurm 2011).

In transient gene expression, non-viral (plasmid vectors) and viral expression vectors have been designed for transferring the genes to mammalian cells. The reasons, which define the expression

*Author for correspondence: eutimiocu@yahoo.com 
vector selection for this purpose are: the recombinant protein application, the host cell, bioprocess time, productivity and safety (Baldi et al. 2007). The purity and recovery of plasmid DNA encoding for interest protein are limiting aspects when non-viral expression vectors are chosen (Geisse and Henke 2005). In general, the major concern for using virus as an expression vector is their infective nature, which involves biological risks (Sakamoto et al. 1999). However, the utilization of replication-deficient viral vectors such as Semliki Forest virus (SFV) and Sindbis virus vectors avoids this problem while allowing rapid and high-level gene delivery (Lundstrom et al. 2001a). This review defines the main advantages and drawbacks of SFV utilization for biopharmaceutical production in the mammalian cells and the present and near future challenges for a wide application of this viral vector on largescale.

\section{TRANSIENT GENE EXPRESSION IN MAMMALIAN CELLS FOR RECOMBINANT PROTEIN PRODUCTION ON LARGE-SCALE}

The transient gene expression used on large-scale for recombinant protein production is a relatively new technology. In the past, the volumetric productivities reached by transient gene expression were not competitive with those from the stable cell lines (Hacker et al. 2009). However, recently, productivity up to $1 \mathrm{~g} / \mathrm{l}$ with HEK-293 cells transfected with plasmid DNA in 14 days bioprocess has been reported (Backliwal et al. 2008). This report encourages new transient gene expressions in order to establish these processes at higher volumetric scales (100-1,000 1 range). Beyond, the technical problems related to this gene expression way in the mammalian cells, there are two limiting events for its consolidation in biopharmaceutical industry:

1. At the present time, there is no therapeutic protein using transient gene expression in mammalian cells that has got regulatory approval.

2. There is a perception in the industry that large-scale transient gene expression is not reproducible.

Both elements could be overcome by targeting a protein with high value, which does not require a large amount of recombinant protein to meet the market demands and by developing robust processes on small-scale using scalable devices, respectively (Hacker et al. 2009). The experience with baculovirus-insect cell expression system for commercial manufacture of various veterinary and human vaccines could be also used to solve the current limitations in mammalian cells systems (Cox 2012).

So far, the non-viral vector methods have been the methods of choice for transient gene expression (Matasci et al. 2008). The recombinant gene is usually cloned in a plasmid DNA and transfected into the single-cell suspension culture. Only three DNA delivery methods for introducing plasmids in mammalian cells have been shown to be promising for large-scale operations: calcium phosphate DNA co-precipitation, polyethyleneimine or liposome DNA complexes and electroporation. These DNA transfer systems have demonstrated transfection efficiencies of more than $70 \%$. After DNA delivery, cells are maintained in the culture for protein production during a limited time span, usually 5-10 days (Wurm and Bernard 1999).

Transient gene expression by viral vectors is carried out introducing the recombinant gene of interest in viruses. The transfer of exogenous DNA or RNA into animal cells, in general, as part of viral particle is named as transduction. The advantage of viral transduction over transfection with naked plasmid DNA includes the high efficiency of gene transfer because a natural delivery process is used. The tendency of many viruses to block the host cell protein synthesis and favor the expression of viral genes is also important for heterologous genes expression, which can increase bioprocess productivity. Besides, different viruses can achieve different transformation objectives: short-term infections with high-level transient expression, long-term expression by maintaining the genome as a latent episomal replicon, or stable integration of DNA into the host cell genome (Twyman 2005). The disadvantages of virus as gene transfer vectors include more complex cloning strategies compared to plasmid vectors, the biosafety problems related to bioprocesses with virus and health risks after recombinant protein administration associated to possible presence of viral vector (Twyman 2005; Lee et al. 2005). Many efforts have been addressed to overcome these problems in viral vectors (Lundstrom et al. 2001b; Chen et al. 2011).

Among the viral vectors for recombinant protein expression in the mammalian cells are vaccinia 
virus (Pradeau-Aubreton et al. 2010), adenovirus (Pham et al. 2006), alphaviruses (Venezuelan Equine Encephalitis virus and Sindbis virus and the SFV) (Quetglas et al. 2010). Despite of the fact that the Baculovirus expression system is a well established methodology in insect cells for producing eukaryotic proteins (Koroleva et al. 2010; Trowitzsch et al. 2010; Gomez-Casado 2011), the use of vectors based on this virus (BacMam) has also demonstrated efficiency in the mammalian cells (Kost et al. 2005).

\section{SEMLIKI FOREST VIRUS (SFV)}

SFV is a single positive-strand RNA virus with an envelope structure. The first part (5'end) of genome encodes the nonstructural proteins, while the second part (3'end) encodes the structural proteins (Dudek and Knipe 2006). Its genome has been introduced into two plasmid vectors as cDNA copies. The expression vector contains the SFV nonstructural genes (nsP1-4), the strong subgenomic SFV 26S promoter and a multilinker cloning region to introduce the foreign genes for recombinant protein expression. The SFV structural proteins are provided from the helper vector, including the envelope and capsid proteins (Liljeström and Garoff 1991). Co-transfection of in vitro transcribed recombinant and helper RNA can generate around $10^{9}-10^{10}$ recombinant viral particles $/ \mathrm{ml}$. These particles have the capacity to infect a wide range of mammalian and other animal cell lines (Lundstrom 2003a). The electroporation is the method of choice for SFV RNAs co-transfection but lipid-mediated transfection can be applied alternatively with relatively good results (Lundstrom 2010).

Because of the presence of RNA packing signal only in the recombinant RNA, no helper RNA will be packaged, which generates replication-deficient particles, increasing vector's biosafety features. To decrease the infection risks, a mutation was inserted in the region encoding the viral spike proteins, inhibiting host entry. Therefore, viral vector could be no-infectious during the storage period and could only be activated in vitro by cleavage with $\alpha$-chymotrypsin (Berglund et al. 1993; Benmaamar et al. 2009). After host cells infection, rapid and high-level transgene expression is obtained. Different proteins have been successfully expressed from the SFV vector. Yields of $10^{9}$ heterologous protein molecules per cell, representing around $25 \%$ of the total cellular protein yields have been obtained by this viral vector (Lundstrom 2003a).

The SFV vectors have become increasingly attractive because of their characteristics of rapid expression of high amounts of recombinant protein. After infection, the RNA replication in the host cell cytoplasm results in measurable transgene expression as early as $2 \mathrm{~h}$ after the infection. In spite of the great potential for widespread use of SFV for recombinant protein production, two major drawbacks are related to this viral vector: the strong cytotoxic effect on host cells and the short-term expression pattern. In addition, SFV infection of cell culture has been demonstrated to induce apoptosis. Solving, or mitigating these problems would expand even more the applications range of this alphavirus vector (Lundstrom 2002; Hassaine et al. 2006).

\section{RECOMBINANT PROTEIN PRODUCTION BY SEMLIKI FOREST VIRUS VECTOR ON LAB-SCALE}

On lab-scale, the SFV vector has been widely used for obtaining sufficient amounts of recombinant proteins for cellular, or molecular assays, pharmacological tests and structural studies (Hoffmann et al. 2001; Werten et al. 2002; Cabaniols et al. 2009). Most of them are functional membrane proteins, receptors (Shukla et al. 2006; Eifler et al. 2007), enzymes (Bikker et al. 1997) and viral proteins (Benmaamar et al. 2009). High volumetric protein expression levels and yields have been obtained by the modified SFV in the mammalian cells, up to $10 \mathrm{mg} \mathrm{l}^{-1}$ and 100-300 pmol $\mathrm{mg}^{-1}$ of total proteins, for $\mathrm{G}$ protein-coupled receptors (Shukla et al. 2007; Sevastsyanovich et al. 2009). The yield enhancement by the use of SFV vector comparing to stable cell lines and other transient transfections could be 20 fold higher (Shukla et al. 2007).

Currently, the studies for improving the SFV as high efficient protein producer vector are, or should be addressed to its genetic modification in order to extend the expression time in the host cells and optimizing the culture parameters during the infection and expression processes such as the host cell lines, temperature, $\mathrm{pH}$, infection and post-infection times and multiplicity of infection (ratio of virus to target cell). The efforts in genetic modifications of the SFV are focused on mutations 
in alphavirus replicase to render this vector less cytopathic (Casales et al. 2010). Host cell lines more used for protein transient expressions with this alphavirus are Baby Hamster Kidney (BHK21), Chinese Hamster Ovary (CHO-K1) and Human Embryonic Kidney (HEK293) in both adherent and suspension cultures (Lundstrom 2003a; Lundstrom 2010). For a single protein expression, the selection of the cell line could be performed through a comparison among available cell lines keeping constant the remaining parameters of cell culture in small volume systems (Blasey et al. 1997; Hassaine et al. 2006).

Deterministic and empiric models definition as well as optimization of the bioprocess parameters on small-scale have not been detailed enough for this expression system. Works in this field could improve the protein expression using the SFV. Probably, the low number of paper on this subject is justified because most of the time, SFV system has been used on lab-scale without seeking to develop subsequently a large-scale bioprocess. For example, a study on temperature demonstrated that the cultures grown at $33^{\circ} \mathrm{C}$ showed an increase of 10-20 fold expression for luciferase and the expression time could be prolonged (up to $50 \mathrm{~h}$ ) when compared to $37^{\circ} \mathrm{C}$ cultures (Schlaeger and Lundstrom 1998). For variables such as the $\mathrm{pH}$ and multiplicity of infection, the investigated ranges in literature are 6.4-7.8 and 30-400, respectively. The protein expression has shown to be very sensitive to small $\mathrm{pH}$ changes over the course of bioprocess and directly related to the multiplicity of infection (Blasey 1997; Blasey 2000). Nevertheless, a modification of pharmacological profile for some recombinant receptors was observed when the cells were infected with increased concentration of virus (Lundstrom 2003b). This could be a consequence of a saturation of right protein synthesis capacity in host cells. Thus, in future, more detailed studies considering the bioprocess variables should be performed on small-scale. This could be possible if the SFV is definitively established on large-scale processes.

\section{CELL CULTURE STRATEGIES FOR OBTAINING RECOMBINANT PROTEINS BY THROUGH SEMLIKI FOREST VIRUS SYSTEM}

Among the alpha virus, only SFV has been used for large-scale recombinant protein production, which showed its popularity because the principles of this kind of vectors are the same. As a rule the cell culture used for transduction should be in exponential growth phase to generate maximal expression levels. To scale-up the Semiliki Forest virus technology, it is absolutely essential to establish efficient infection and expression conditions in suspension cultures of the mammalian cells. In that sense, for reducing the cell costs and to facilitate the purification of recombinant proteins, CHO, HEK293 and BHK lines were adapted in suspension growth in serumfree medium without the decrease in expression level (Lundstrom 2003b). For high volume cultures, compromises need to be made between the optimal virus concentration and feasible virus production. The main disadvantage of applying the SFV system for the large-scale production of the protein is the high cost of virus stock production related to in vitro transcription process (Lundstrom 2010) (Fig. 1). In order to reduce the cost for virus preparation, alpha virus packaged cell lines have been developed (Polo et al. 1999; Blasey et al. 2000). This approach could simultaneously increase the production of viral particles.

There are a few studies related to SFV utilization on large-scale protein production by the utilization of bioreactors, spinner (11) and agitated tank (11.5l) for producing the enzymes (bacterial $\beta$ galactosidase and human cyclooxygenase-2) and 5-HT3 receptor (Blasey et al. 1997; Blasey et al. 2000) The culture strategies to perform these bioprocesses were fed-batch and external medium exchange (Fig. 2).

In the fed-batch process, the SFV was inoculated in $10-20 \%$ bioreactor volume and BHK cells were kept in contact with the virus for $90 \mathrm{~min}$, and then fresh culture medium was added to complete the bioreactor volume. The bioprocess after the infection step lasted $20 \mathrm{~h}$. High level protein expression $\left(16 \mathrm{mg} \mathrm{l}^{-1}\right)$ was generated in a short time (Blasey et al. 1997). On the other hand, in external medium exchange process, $90 \%$ of exhausted culture medium used for the BHK batch cell culture was changed by fresh medium by external cross-flow filtration with a hollow fiber microfilter. Then the BHK cells were infected with the modified SFV for $24 \mathrm{~h}$ (Fig. 2). 
Semliki Forest virus

expression vector
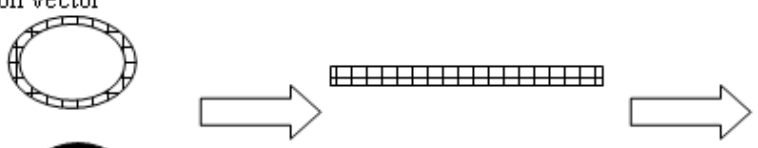

(1)

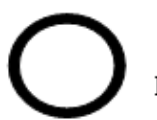

Plasmid DNA linearization

In vitro transcription

Semliki Forest virus helper vector
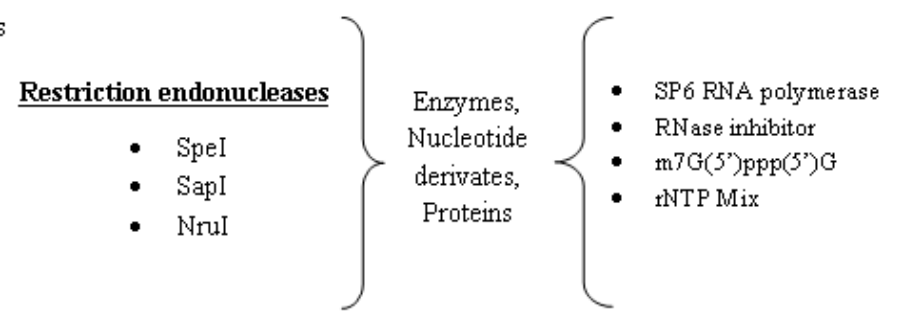

Figure 1 - In vitro transcription process for Semliki Forest virus vector and its more costly reagents.
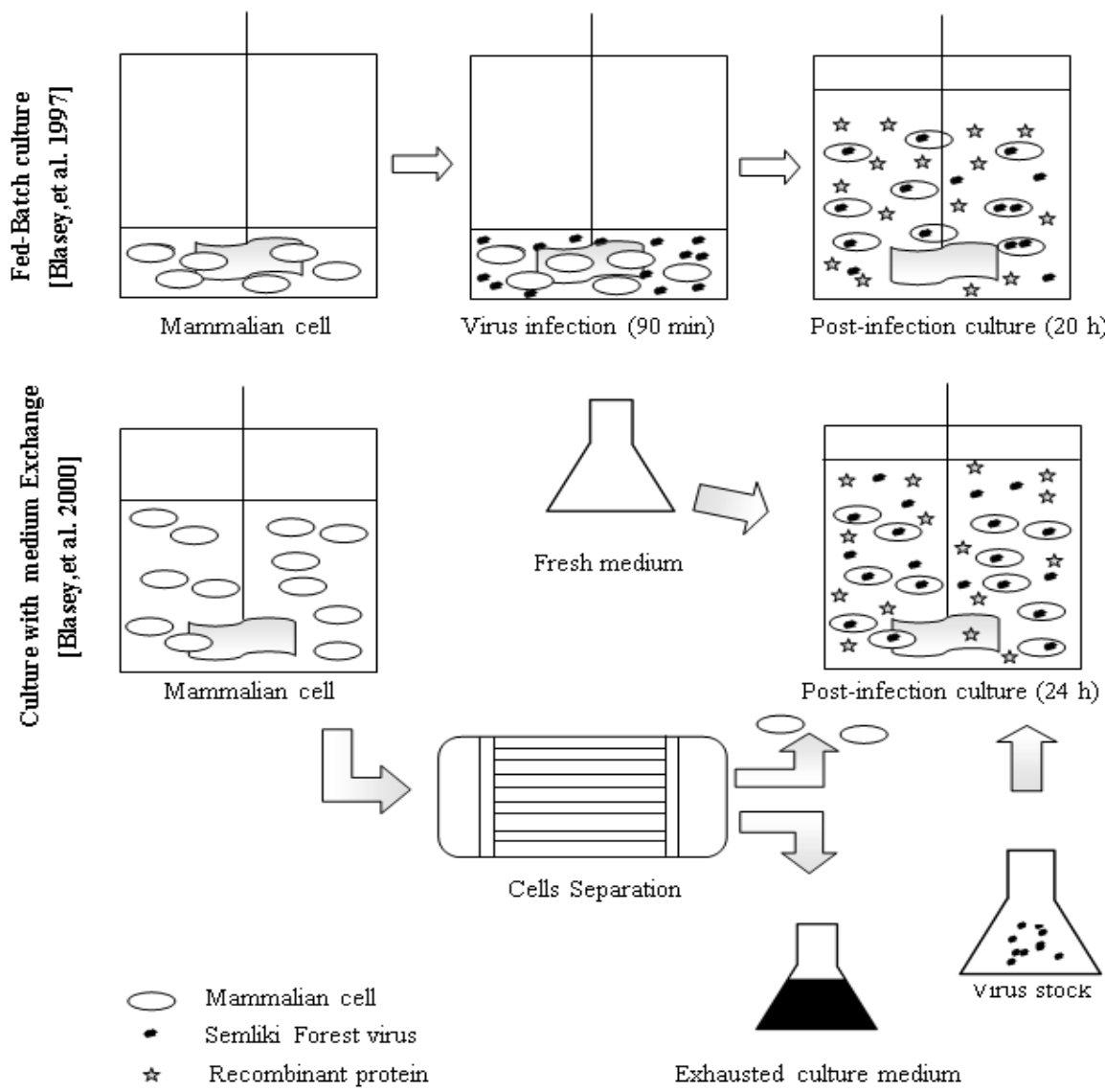

Post-infection culture ( $24 \mathrm{~h})$

Fresh medium
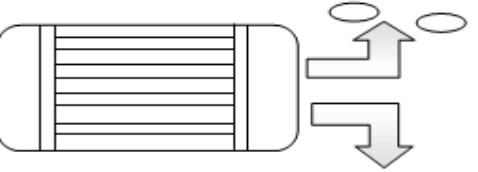

Cells Separation
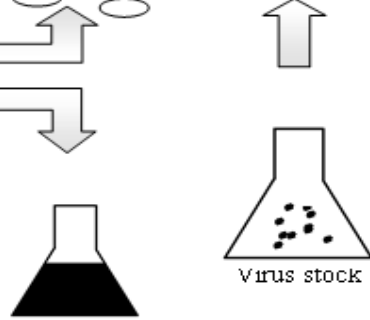

- Semliki Forest virus

Exhausted culture medium

Figure 2 - Culture strategies for transduction and protein expression with Semliki Forest virus on large-scale.

This strategy allowed the expression of $15 \mathrm{mg}$ of 5-HT3 receptors per 11.51 batch (Blasey et al. 2000). The volumetric productivities for both the processes were higher than those usually obtained for bioprocess with stably transfected mammalian cells (>0.05 $\mathrm{mg} \mathrm{l}^{-1}$ for human membrane protein) (Chaudhary et al. 2011). Despite these good performances of this viral vector in the expression 
of associated and integral membrane proteins (used in the pharmacological studies), besides the costs of RNA in vitro transcription, one of the main challenges related to the SFV vector applications in biopharmaceuticals production is the understanding of metabolic patterns during the infections in order to define the suitable culture medium and bioprocess strategies for improving the volumetric productivity. Then, the SFV vector could achieve equivalent performance with stable cell lines $\left(>1 \mathrm{~g} \mathrm{l}^{-1}\right)$.

Another problem, which limits the use of this transient expression vector in high volume bioreactors is virus transduction into the cell because of high cost and low efficiency. In this regard flow electroporation could be an interesting option (Parham et al. 1998). On the other hand, from the analytical point of view, the difficulties related to the establishment of accurate techniques for viral particles quantification (Calgua et al. 2011) could delay the standardization of biopharmaceutics manufacturing based on the SFV vector.

\section{CONCLUSIONS}

The SFV, as also the rest of viral vectors for protein transient expression, has been underutilized on large-scale, despite of its high expression level on small-scale. Four most critical aspects should be considered in order to establish definitively this vector as a suitable alternative for biopharmaceutical in high volume bioreactors: reduced cost for the production of virus, suitable culture medium and feed strategies over the course of post-infection stage and transduction process, as well as the precise method for viral particles quantification.

\section{ACKNOWLEDGMENTS}

The authors would like to thank Fundação de Amparo à Pesquisa do Estado de São Paulo for post-doctoral fellowship (2010/52521-6) and Conselho Nacional de Desenvolvimento Científico e Tecnológico $(\mathrm{CNPq})$ for scientific grant. First author gratefully acknowledges Relma Tavares de Oliveira Fernández and PhD. Rodolfo Valdés, for the inspiration to write this paper. Carlos A Pereira is recipient of a senior $1 \mathrm{~A} \mathrm{CNPq}$ fellowship.

\section{REFERENCES}

Backliwal G, Hildinger M, Chenuet S, Wulhfard S, De Jesus M, Wurm FM. Rational vector design and multi-pathway modulation of HEK 293E cells yield recombinant antibody titers exceeding $1 \mathrm{~g} / \mathrm{l}$ by transient transfection under serum-free conditions. Nucleic Acids Res. 2008; 36(15): e96.

Baldi L, Hacker DL, Adam M, Wurm FM. Recombinant protein production by large-scale transient gene expression in mammalian cells: state of the art and future perspectives. Biotechnol Lett. 2007; 29(5): 677-684.

Benmaamar R, Astray RM, Wagner R, Pereira CA. High-level expression of rabies virus glycoprotein with the RNA-based Semliki Forest Virus expression vector. J Biotechnol. 2009; 139(4): 283-290.

Berglund P, Sjöberg M, Garoff H, Atkins GJ, Sheahan BJ, Liljeström P. Semliki Forest virus expression system: production of conditionally infectious recombinant particles. Biotechnology. 1993; 11(8): 916-920.

Bikker H, Baas F, de Vijlder J-JM. Molecular analysis of mutated thyroid peroxidase detected in patients with total iodide organification defects. $J$ Clin Endocrinol Metab. 1997; 82(2): 649-653.

Blasey HD, Brethon B, Hovius R, Vogel HH, Tairi AP, Lundström K, et al. Large scale transient 5-HT3 receptor production with the Semliki Forest Virus Expression System. Cytotechnology. 2000; 32(3): 199-208.

Blasey HD, Lundström K, Tate S, Bernard AR. Recombinant protein production using the Semliki Forest Virus expression system. Cytotechnology. 1997; 24(1): 65-72.

Cabaniols JP, Mathis L, Delenda C. Targeted gene modifications in drug discovery and development. Curr Opin Pharmacol. 2009; 9(5): 657-663.

Calgua B, Barardi CR, Bofill-Mas S, RodriguezManzano J, Girones R. Detection and quantitation of infectious human adenoviruses and JC polyomaviruses in water by immunofluorescence assay. J Virol Methods. 2011: 171(1): 1-7.

Casales E, Aranda A, Quetglas JI, Ruiz-Guillen M, Rodriguez-Madoz JR, Prieto J, et al. A novel system for the production of high levels of functional human therapeutic proteins in stable cells with a Semliki Forest virus noncytopathic vector. $N$ Biotechnol. 2010; 27(2): 138-148.

Chaudhary S, Pak JE, Pedersen BP, Bang LJ, Zhang LB, Ngaw SM, et al. Efficient expression screening of human membrane proteins in transiently transfected Human Embryonic Kidney 293S cells. Methods. 2011; 55(4): 273-280.

Chen CY, Lin CY, Chen GY, Hu YC Baculovirus as a gene delivery vector: recent understandings of molecular alterations in transduced cells and latest applications. Biotechnol Adv. 2011; 29: 618-631. 
Conceição MM, Tonso A, Freitas CB, Pereira CA. Viral antigen production in cell cultures on microcarriers Bovine parainfluenza 3 virus and MDBK cells. Vaccine. 2007; 25(45): 7785-7795.

Cox MMJ. Recombinant protein vaccines produced in insect cells. Vaccine 2012; 30(10): 1759-1766.

De Jesus M, Wurm FM. Manufacturing recombinant proteins in kg-ton quantities using animal cells in bioreactors. Eur J Pharm Biopharm. 2011; 78(2): 184-188.

Dudek T, Knipe DM. Replication-defective viruses as vaccines and vaccine vectors. Virology. 2006; 344(1): 230-239.

Eifler N, Duckely M, Sumanovski LT, Egan TM, Oksche A, Konopka JB, et al. Functional expression of mammalian receptors and membrane channels in different cells. J Struct Biol. 2007; 159(2): 179-193.

Geisse S, Henke M. Large-scale transient transfection of mammalian cells: a newly emerging attractive option for recombinant protein production. J Struct Funct Genomics. 2005; 6(2-3): 165-170.

Gomez-Casado E, Gomez-Sebastian S, Núñez MC, Lasa-Covarrubias R, Martínez-Pulgarín S, Escribano JM. Insect larvae biofactories as a platform for influenza vaccine production. Protein Expr Purif. 2011; 79(1): 35-43.

Hacker DL, De Jesus M, Wurm FM. 25 years of recombinant proteins from reactor-grown cells where do we go from here? Biotechnol Adv. 2009; 27(6): 1023-1027.

Hassaine G, Wagner R, Kempf J, Cherouati N, Hassaine N, Prual C, et al. Semliki Forest virus vectors for overexpression of $101 \mathrm{G}$ protein-coupled receptors in mammalian host cells. Protein Expr Purif. 2006; 45(2): 343-351.

Hoffmann M, Verzijl D, Lundstrom K, Simmen U, Alewijnse AE, Timmerman $\mathrm{H}$, et al. Recombinant Semliki Forest virus for over-expression and pharmacological characterisation of the histamine $\mathrm{H}(2)$ receptor in mammalian cells. Eur J Pharmacol. 2001; 427(2): 105-114.

Kerrigan JJ, Xie Q, Ames RS, Lu Q. Production of protein complexes via co-expression. Protein Expres Purif. 2011; 75(1): 1-14.

Koroleva NN, Spirin PV, Timokhova AV, Rubtzov PM, Kochetkov SN, Prasolov VS, et al. Baculovirus vectors for efficient gene delivery and expression in mammalian cells. Mol Biol. 2010; 44(3): 479-487.

Kost TA, Condreay JP, Jarvis DL. Baculovirus as versatile vectors for protein expression in insect and mammalian cells. Nat Biotechnol. 2005; 23(5): 567575.

Lee JS, Hadjipanayis AG, Parker MD. Viral vectors for use in the development of biodefense vaccines. $A d v$ Drug Deliver Rev. 2005; 57(9): 1293-1314.

Liljeström P, Garoff H. A new generation of animal cell expression vectors based on the Semliki Forest virus replicon. Nat Biotechnol. 1991; 9(12): 1356-1361.
Lundstrom K, Schweitzer C, Rotmann D, Hermann D, Schneider EM, Ehrengruber MU. Semliki Forest virus vectors: efficient vehicles for in vitro and in vivo gene delivery. FEBS Letters. 2001a; 504(3): 99103.

Lundstrom K, Rotmann D, Hermann D, Schlaeger EJ. Safety aspects related to recombinant protein expression from Semliki Forest virus vectors. Cytotechnology. 2001b; 35(3): 213-221.

Lundstrom K. Expression of Mammalian Membrane Proteins in Mammalian Cells Using Semliki Forest Virus Vectors. In: Mus-Veteau I, editor. Heterologous Expression of Membrane Proteins, Methods in molecular Biology. New York: Humana Press; 2010. p. 149-164.

Lundstrom K. Semliki Forest virus vectors for rapid and high-level expression of integral membrane proteins. Biochim Biophys Acta. 2003a; 1610(1): 90-96.

Lundstrom K. Semliki Forest Virus Vectors for LargeScale Production of Recombinant Proteins. In: Machida CA, editor. Viral vectors for gene therapy. Methods and Protocols, New Jersey: Humana Press; 2003b.p. 525-544.

Lundstrom K. Semliki forest virus-based expression for versatile use in receptor research. J Recept Signal Tr. 2002; 22 (1-4): 229-240.

Matasci M, Hacker DL, Baldi L, Wurm, FM. Recombinant therapeutic protein production in cultivated mammalian cells: current status and future prospects. Drug Discov Today Technol. 2008; 5(2-3): 37-42.

Parham JH, Iannone MA, Overton LK, Hutchins JT. Optimization of transient gene expression in mammalian cells and potential for scale-up using flow electroporation. Cytotechnology. 1998; 28(1-3): 147-155.

Pham PL, Kamen A, Durocher Y. Large-scale transfection of mammalian cells for the fast production of recombinant protein. Mol Biotechnol. 2006; 34(2): 225-237.

Polo JM, Belli BA, Driver DA, Frolov I, Sherril S, Hariharan MJ, et al. Stable alphavirus packaging cell lines for Sindbis virus and Semliki Forest virusderived vectors. Proc Natl Acad Sci USA. 1999; 96(8): 4598-4603.

Pradeau-Aubreton K, Ruff M, Garnier JM, Schultz P, Drillien R. Vectors for recombinational cloning and gene expression in mammalian cells using modified vaccinia virus Ankara. Anal Biochem. 2010; 404(1): 103-105.

Quetglas JI, Ruiz-Guillen M, Aranda A, Casales E, Bezunartea J, Smerdou C. Alphavirus vectors for cancer therapy. Virus Res. 2010; 153(2): 179-196.

Sakamoto S, Ide T, Tokiyosi S, Nakao J, Hamada F, Yamamoto M, et al. Studies on the structures and antigenic properties of rabies virus glycoprotein analogues produced in yeast cells. Vaccine. 1999; 17(3): 205-218. 
Schlaeger EJ, Lundstrom K. Effect of temperature on recombinant protein expression in Semliki Forest virus infected mammalian cell lines growing in serum- free suspension cultures. Cytotechnology. 1998; 28(1-3): 205-211.

Sevastsyanovich Y, Alfasi S, Cole J Recombinant protein production: a comparative view on host physiology. N Biotechnol. 2009; 25 (4): 175-180.

Shukla AK, Haase W, Reinhart C, Michel H. Biochemical and pharmacological characterization of the human bradykinin subtype 2 receptor produced in mammalian cells using the Semliki Forest virus system. Biol Chem. 2006; 387(5): 569-576.

Shukla AK, Haase W, Reinhart C, Michel H. Heterologous expression and comparative characterization of the human neuromedin U subtype II receptor using the methylotrophic yeast Pichia pastoris and mammalian cells. Int J Biochem Cell Biol. 2007; 39(5): 931-942.
Trowitzsch S, Bieniossek C, Nie Y, Garzoni F, Berger I. New baculovirus expression tools for recombinant protein complex production. J Struct Biol. 2010; 172(1): 45-54.

Twyman RM. Gene transfer to animal cells. New York: Garland BIOS Scientific Publishers; 2005.

Walsh G. Post-translational modifications of protein biopharmaceuticals. Drug Discov Today. 2010; 15(17-18): 773-780.

Werten PJ, Rémigy HW, de Groot BL, Fotiadis D, Philippsen A, Stahlberg $\mathrm{H}$, et al. Progress in the analysis of membrane protein structure and function. FEBS Letters. 2002; 529(1): 65-72.

Wurm F, Bernard A. Large-scale transient expression in mammalian cells for recombinant protein production. Curr Opin Biotechnol. 1999; 10(2): 156-159.

Received: June 13, 2012; Accepted: July 05, 2013. 